would otherwise be most influenced by initial tumour grading. Unfortunately possible drawbacks may have been overlooked in the initial wave of enthusiasm. ${ }^{17}$ The complexity of the technique is usually underestimated and should deter inexperienced laboratory workers. Few of the published studies list patients' blood groups. These data might have an important bearing on a population showing predominance of group $\mathrm{O}$, since the $\mathrm{H}$ antigen is more difficult to identify than $\mathrm{A}$ or $\mathrm{B}$. Another problem is how the result should be quantified. Some workers will register a positive test only when every epithelial surface is covered with the indicator cells, while others attempt to arrange the results on an arbitrary scale, considering the test positive for the top two or three out of four grades. There may even be variation in staging tumours for correlating the extent of invasion by recurrent growth with the specific redcell-adherence reaction. Though strict interpretation would mean that any tumour not affecting muscle should be labelled as non-invasive, surely the extension of recurrent growth through the basement membrane and lamina propria should not be placed in the same broad category as tumours restricted to the mucosa. So one of the uncertainties is how many of the initial "non-invasive" tumours with antigen deletion had in fact shown signs of early invasion.

These and other problems may explain inconsistencies in the test results which may be confused with changes in reactivity of possible biological importance. Certainly some explanation is needed of the considerable variation in the errors of prediction of subsequent behaviour of the tumour among different studies on similar groups of patients from different centres ${ }^{18}$ and of reports of patients showing variable serial reactivity. ${ }^{9}$ Another possible cause of confusion of any clear relation between loss of antigen and prognosis is that radiotherapy might restore reactivity to an invasive tumour. ${ }^{19}$ If it could be shown that patients in whom such a change occurred were those who responded to treatment by a reduction in the stage of their tumour the test might again have prognostic significance. Unfortunately the findings of this particular study were virtually invalidated by the fact that different groups were compared before and after treatment.

In a recent publication ${ }^{20}$ the authors showed that antigen deletion was best interpreted according to known synthetic pathways of blood group antigens. Their results suggest that the action of malignant cells is to suppress to a variable extent conversion of $\mathrm{H}$ to $\mathrm{A}$ and $\mathrm{B}$ antigens and perhaps $\mathrm{H}$ from precursor substance. If that is so then data on the presence or absence of $\mathrm{A}, \mathrm{B}$, and $\mathrm{H}$ antigens singly are insufficient, and all must be assayed in any one tumour to define degrees of antigen deletion. This study also underlies a possible drawback from the use of paraffin sections: in the past the potential degradation of the glycolipid element of these surface antigens by the dewaxing process may have been overlooked.

The future of the test is uncertain. More reliable methods are needed for identifying antigens, possibly with the help of monospecific antibodies. Quantitation must be standardised, and the question of how tissue should be fixed and embedded quickly resolved. The most useful studies will probably be those that are prospective with serial determinations on frozen sections.

Consultant Urologist,

University Hospital,

Nottingham NG7 2UH

${ }^{1}$ Coombs RRA, Bedford D, Rouillard LM. A and B blood-group antigens on human epidermal cells. Demonstrated by mixed agglutination. Lancet $1956 ; \mathrm{i}: 461-3$.

${ }^{2}$ Davidsohn I. Early diagnosis and prognosis of carcinoma. Am $\mathrm{f}$ Clin Pathol 1972;57:715-30.
${ }^{3}$ Kay HEM, Wallace DM. A and B antigens of tumors arising from urinary epithelium FNCI $1961 ; 26: 1349-65$.

${ }^{4}$ Askari A, Colmenares E, Saberi A, Jarman WD. Red cell surface antigen and its relationship to survival of patients with transitional cell carcinoma of the bladder. F Urol $1981 ; 125: 182-4$.

${ }^{5}$ Bergman S, Javadpour $\mathrm{N}$. The cell surface antigen $\mathrm{A}, \mathrm{B}$ or $\mathrm{O}(\mathrm{H})$ as indicator of malignant potential in stage A bladder carcinoma : preliminary report. $\mathcal{f}$ Urol $1978 ; 119: 49-51$

${ }^{6}$ Cummings K. Carcinoma of the bladder: predictors. Cancer $1980 ; 45$ : 1849-55.

${ }^{7}$ Emmott RC, Javadpour N, Bergman SM, Soares T. Correlation of the cell surface antigens with stage and grade in carcinoma of the bladder. $\mathcal{F}$ Urol $1979 ; 121: 37-9$

8 Johnson JD, Lamm DL. Prediction of bladder tumor invasion with the mixed cell agglutination test. $\mathcal{f}$ Urol $1980 ; 123: 25-8$

${ }^{9}$ Limas C, Lange P, Fraley EE, Vessella RL. A, B, H antigens in transitional cell tumors of the urinary bladder. Correlation with the clinical course. Cancer 1979;44:2099-107.

10 Newman AJ Jr, Carlton CE, Johnson S. Cell surface A, B or $\mathrm{O}(\mathrm{H})$ blood group antigens as an indicator of malignant potential in stage $\mathrm{A}$ bladder carcinoma. F Urol 1980;124:27-9.

${ }^{11}$ Richie JP, Blute RD, Waisman J. Immunological indicators of prognosis in bladder cancer. The importance of cell surface antigens. $\mathcal{F}$ Urol 1980 ; $123: 22-4$.

12 Young AK, Hammond E, Middleton AW Jr. The prognostic value of cell surface antigens in low grade, non-invasive transitional cell carcinoma of the bladder. 7 Urol $1979 ; 122: 462-4$.

${ }^{13}$ Limas C, Lange P. Altered reactivity for A, B, H antigens in transitional cell carcinoma of the urinary bladder. A study of the mechanisms involved. Cancer 1980;46:1366-73.

14 Jakse G, Hofstädter F. Further experiences with the specific red cell adherence test (SRCA) in bladder cancer: a histological and cytological study. Eur Urol 1978;4:356-60.

15 Emmott RC, Droller MJ, Javadpour N. Studies of A, B, or $\mathrm{O}(\mathrm{H})$ surface antigen specificity: carcinoma in situ and non-malignant lesions of the bladder. $\mathcal{F}$ Urol $1981 ; 125: 32-5$.

${ }^{16}$ Catalona WJ. Practical utility of specific red cell adherence test in bladder cancer. Urology $1981 ; \mathbf{1 8}: 113-7$.

17 Ramsey EW. Specific red cell adherence technique. $\mathcal{F}$ Urol 1980;124:304

${ }^{18}$ Lange PH, Limas C. Tissue blood group antigen testing in transitional cell carcinoma of the bladder. F Urol 1980;124:304.

19 Alroy J, Teramura $\mathrm{K}$, Miller AW, et al. Isoantigens A, B and $\mathrm{H}$ in urinary bladder carcinomas following radiotherapy. Cancer $1978 ; 41: 1739-45$.

${ }^{20}$ Fujita J, Matsumoto K, Kishi K, Ishiyama I. Synthesis of ABH blood group substances in bladder tumours. Br $\mathcal{F}$ Urol $1981 ; 53: 448-52$.

\section{Problems of clubfeet}

Clubfoot-talipes equinovarus-has been recognised as far back as ancient Egypt, and a statue of a dystrophic dwarf with a clubfoot is in the Tutankhamun collection. ${ }^{1}$ It remains the most difficult of orthopaedic congenital anomalies to treat successfully. The problem is to correct a deformity which is in three planes and affects several joints at the same time, in an environment which is constantly changing under the influence of growth. ${ }^{2}$ Twenty years ago Gartland stated ${ }^{3}$ that "we are still grappling with a disorder the cause of which is unknown, the pathological anatomy uncertain, the behaviour unpredictable, and the treatment controversial," and his words remain true today.

Most investigators have reported an incidence of 1-2 per 1000 live births. Boys are more frequently affected than girls by about $2: 1$. Wynne-Davies ${ }^{4}$ investigated genetic factors, finding a rise in incidence among first-degree relations and siblings; the rate of 2.9 per 100 is between 20 and 30 times greater than normal. The only large twin study, from Germany in $1939,{ }^{5}$ found that 13 out of 40 monozygotic co-twins were concordant but only four of 134 dizygotic twins were. This wide difference indicates a strong genetic factor, though environmental influences must also play a part.

Histochemical analysis and electron microscopy of calf muscle biopsy specimens taken from 60 children under 5 years old have suggested that there is an important neurogenic factor in the development of clubfoot. ${ }^{6}$ In a similar type of 
investigation but with controls Gray and $\mathrm{Katz}^{7}$ found that the muscle structure was normal but that the calf muscles were reduced in size owing to a reduction in the number of fibres rather than in their size. This explains the pipestem calf so often seen in association with clubfoot - an abnormality which is often blamed on the treatment with its prolonged immobilisation in plaster casts.

Treatment cannot begin too early. The vital period is from birth to 1 year, for if the defect is not corrected during this phase success is unlikely in the future. Denham has observed that the bones are the soft and vulnerable elements of a baby's foot, whereas the ligaments are resistant ${ }^{8}$; continued attempts at correction may cause compression of the dome of the talus or produce a rocker-bottom sole as a result of a coronal breach of the foot in the midtarsal area.

For treatment clubfeet fall into two broad categories, those which are very easy to correct and those which are severe and resistant. ${ }^{9}$ When children with defects in the first category are seen shortly after birth the foot can be corrected almost at once to the neutral position or beyond by gentle stretching without an anaesthetic. Full correction can be produced rapidly by frequent manipulations supplemented by the support of strapping or plaster casts. This type of foot is recognised by the ease with which the heel can be seen and felt, and the defect should be looked on as a persistent fetal position. In clubfeet of the second type the calcaneum may be difficult to feel, and careful palpation will show that it is tucked up behind the tibia. After preliminary stretching and strapping, early operationat 4 to 6 weeks-is advisable. The operative correction is performed through a posteromedial approach, the aim being to divide and lengthen all the tight structures holding the foot in the equinovarus position such as the tendo Achillis, the deep flexor tendons, and the posterior capsule of the ankle and subtalar joints. Release of a tethering band on the lateral side of the ankle may make the problem of full correction easier. ${ }^{10}$ Surgical treatment usually needs to be followed by a period of immobilisation in plaster and later by the use of splints such as the Denis Browne bootee.

Regular and careful supervision is mandatory throughout the period of growth. Radiographs are of value in assessing the quality of the reduction but are difficult to interpret in the child under 1 year-since the ossification centre of the talus is not always centrally situated in the bone.11 The centres of ossification are usually late in appearing and the navicular may not be seen until after the third year. There are also practical problems in positioning the infant's foot accurately to obtain standard views. Any tendency to relapse (sometimes disputed as incomplete correction) may be overcome by additional surgical procedures to balance the foot, such as tendon transfers or osteotomy of the calcaneum. Sometimes final correction may be achieved only when the foot has fully grown and a triple arthrodesis can be carried out: removal of appropriate wedges from the subtalar and midtarsal joint ensures a plantigrade foot. This type of correction, however, is essentially a confession of failure, as it is brought about at the cost of a rigid hindfoot.

Effective management during the growth period will result in plantigrade and mobile feet which are painless and allow a wide range of physical activities. The patient's satisfaction correlates with the mobility at the ankle and in subtalar and midtarsal joints. ${ }^{12}$ Nevertheless, evaluation of the results of treatment is difficult, and few studies have followed children from infancy to the end of growth with careful documentation. A 30-year follow-up study in Sweden of 106 patients aged 27-33 years found that $88 \%$ of the feet surveyed did not look normal. ${ }^{13}$ One-fifth of the patients had some discomfort such as pain, tiredness, or instability. Half of the men with unilateral clubfoot and a quarter with bilateral deformities could take part in active sports, mainly ball games. Most were able to wear "shop" shoes but 14 needed insoles or modifications to the heels or soles of their shoes and four needed orthopaedic footwear. Two-thirds of the patients seen for review had an abnormal degree of wear on the lateral side of their shoes.

Steady progress has been made in the treatment and understanding of clubfeet over the past 50 years, but much remains to be done.

LESLIE KLENERMAN

Consultant Orthopaedic Surgeon,

Northwick Park Hospital,

Harrow,

Middlesex HA1 3UJ

1 Turco VJ. Club foot. Edinburgh: Churchill Livingstone, 1981.

2 Lloyd-Roberts GC. Orthopaedics in infancy and childhood. Sevenoaks, Kent: Butterworths, 1971.

3 Gartland JJ. Posterior tibial transplant in the surgical treatment of recurrent club foot. A preliminary report. F Bone foint Surg (Am) 1964; 46A: $1217-25$.

4 Wynne-Davies R. Family studies and the cause of congenital club foot. Talipes equinovarus, talipes calcaneo-valgus and metatarsus varus. $\mathscr{f}$ Bone foint Surg $(\mathrm{Br}) 1964$;46B :445-63.

5 Wynne-Davies R. Heritable disorders in orthopaedic practice. Oxford: Blackwell Scientific Publications, 1973.

${ }^{6}$ Isaacs $\mathrm{H}$, Handelsman JE, Badenhorst $\mathrm{M}$, Pickering A. The muscles in club foot-a histological, histochemical and electron microscopic study. f Bone foint Surg (Br) 1977;59B:465-72.

7 Gray DH, Katz JM. A histochemical study of muscle in club foot. $\mathcal{F}$ Bone foint Surg $(B r) 1981 ; 63 B: 417-23$.

${ }^{8}$ Main BJ, Crider RJ, Polk M, Lloyd-Roberts GC, Swann M, Kamdar BA The results of early operation in talipes equino-varus. $\mathcal{F}$ Bone foint Surg (Br) $1977 ;$ 59B :337-41.

9 Attenborough CG. Severe congenital talipes equinovarus. $\mathcal{F}$ Bone foint Surg $(B r) 1966 ; 48 B: 31-9$.

${ }^{10}$ Hosking SW, Scott WA. A study of the anatomy and biomechanics of the ankle in normal and club feet (talipes equino varus) of infants. $\mathcal{F}$ Anat (in press).

11 Shapiro F, Glimcher MJ. Gross and histological abnormalities of the talus in congenital club foot. $\mathcal{F}$ Bone foint Surg $(\mathrm{Am})$ 1979;61A:522-30.

${ }^{12}$ Laaveg SJ, Ponseti IV. Long-term results of treatment of congenital club foot. $\mathcal{F}$ Bone foint Surg (Am) 1980;62A :23-31.

13 Bjonness $T$. Congenital clubfoot. A follow-up of 95 persons treated in Sweden from 1940-1945 with special reference to their social adaptation and subjective symptoms from the foot. Acta Orthop Scand $1975 ; 46$ : 848-56.

\section{Compensation: who cares?}

Perhaps we need a new disaster if Britain is ever to get a juster and more efficient system of compensating the incapacitated-because only disasters make things happen. The long-drawn-out battle for compensation for the victims of the thalidomide tragedy led the Government to set up in 1973 the Pearson Commission to consider compensation for death or personal injury. ${ }^{1}$ The commission was not asked to consider the possibility of compensating all incapacitated people, but it nevertheless laboured over its limited remit for five years and made some far from revolutionary proposals. Many of its suggestions amounted to a continuation of the status quo, but it did recommend a no-fault system (injured people would be compensated from a central fund without having to prove fault on anybody's part) for road injuries, and the introduction of strict liability (the injured person would have to go through the courts but would not have to prove negligence) for injury by defective products.

Little has happened since: the no-fault scheme for road 